\title{
The Attitudes of Local Communities Towards Sustainable Development and Development of Ketapan Rame Tourist Village, Mojokerto
}

\author{
Veny Megawati ${ }^{1, *}$, Siti Rahayu ${ }^{2}$, Stefanus Budy Widjaja Subali ${ }^{3}, \&$ Fitri \\ Novika Widjaja $^{4}$
}

\author{
${ }^{1}$ Unversity of Surabaya, Surabaya, Indonesia \\ ${ }^{2}$ Unversity of Surabaya, Surabaya, Indonesia \\ ${ }^{3}$ Unversity of Surabaya, Surabaya, Indonesia \\ ${ }^{4}$ Unversity of Surabaya, Surabaya, Indonesia \\ *Corresponding author.Email: veny_megawati@staff.ubaya.ac.id
}

\begin{abstract}
This study aims to examine the relationship between the local community's attitudes and the sustainable development and development of Ketapan Rame Tourist Village, Mojokerto. This research employed quantitative research methods with data analysis using SPSS 18.0 software. The sampling technique used is non-probability sampling, with a total sample of 154 respondents, who are at least 17 years old and over and are local Ketapan Rame village residents. This study indicates a direct relationship between economic benefits, sociocultural impacts, and local communities' infrastructure on the sustainable development and development of Ketapan Rame tourist village, Mojokerto. Yet, environmental impacts and age aspects are not proven to have a relationship with the sustainable development and development of the village. Testing on gender and education level shows no significant difference in supporting the development of the village.
\end{abstract}

Keywords: Sustainable development, tourist village, economic benefits, socio-cultural impacts, infrastructure.

\section{INTRODUCTION}

These days, the importance of tourism is determined by various economic, social, and cultural sectors. Tourism can also provide positive impacts such as employment, prosperity, improved infrastructure, and increased income. Over the last few decades, the tourism sector has become a powerful agent of change in the economy mainly due to its positive economic impact on society. The primary role of rural areas in the tourism sector is not only due to its position as a superior region but also as an ecological oasis combined with preserving traditional culture and ethnocultural heritage. Rural tourism is a primary factor in appropriate socio-economic development by involving the community in this development (Muresan et al. 2016).

Since the 70s, people's attitudes and perceptions on the impacts of tourism have been analyzed extensively by the tourism industry, policymakers, and academics. 
Ap (1992) suggests a social exchange theory to determine people's positive or negative motivation towards tourism. Tourism is highly dependent on the goodwill of local people. Community support is critical for the development, success, and sustainability of tourism in the long term. Moreover, community attachment influences their perceptions of the impacts of tourism and the relationship between the community and tourists. Tourists are more interested in tourist destinations where people are honest and friendly. Local communities must be involved and active in planning and managing local tourism policies to attach and encourage them to support and carry out the policies (Brida et al. 2014).

In developing countries, local people's participation in tourism development decision-making processes is quite lacking. Local people are often neglected in the planning, decision-making, and management of tourism development projects (Eshliki and Kaboudi 2012).

Tourist villages are part of sustainable tourism development and one of the Republic of Indonesia Government's programs that aims to accelerate the awakening and trigger tourism growth. In line with the Minister of Tourism Regulation of the Republic of Indonesia No 29 of 2015, the development of rural-based tourism (tourist village) will drive economic tourism activities in village areas, preventing the urbanization of village communities to cities. The development of tourist villages will encourage the preservation of nature (landscapes, rice fields, rivers, and lakes), which will reduce global warming. The tourist village program continues to grow as alternative tourism, which is expected to contribute positively to community economic development (https://www.kemenparekraf.go.id/).

The importance of tourism and the development of tourist villages in various countries have attracted researchers to research this field. Bakri et al. (2014) study local people's perceptions of tourism development in Langkawi. Brida et al. (2014) stipulate public perceptions in the impacts of tourism and tourism policies. The research was conducted in a mountainous community in Folgaria, Italy. Bayram et al. (2018) study public perceptions of tourism's impacts in Sinop province, Turkey.

This research replicates Muresan et al. (2016) study about public perceptions of the impacts of tourism and how public support is for future tourism development in NordVest Romania. Replicating Muresan's study, this research conducts a similar study with the object in Ketapan Rame village. Ketapan Rame Village is a tourist area with a fertile mountainous area and a cool climate, located in Trawas District, Southern part of Mojokerto Regency, East Java.

At the end of 2018, Ketapan Rame Village launched the construction of Ganjaran Park as an open space that can be used for the wider community. The development of the park was funded by the District, amounting to IDR 5 billion. In addition to the park, this village has excellent potential in a coffee plantation and won first place in the East Java Coffee Festival in 2018. The village was then developed into a tourist village with the potential for culinary centers and coffee plantations.

Ganjaran Park was expanded by opening a tourist area whose investment was from residents with a profit-sharing system with BUMDES. The next expansion was carried out by selling shares worth IDR 1 million per share to residents. Each household may purchase a maximum of 10 shares, and this activity was able to collect capital worth IDR 3.8 billion. Currently, the remaining operating income (SHU) has been distributed to shareholders with an average income of 50,000-90,000 rupiah/share/ month. The construction of the swimming pool was carried out with a village fund of IDR 350 million. The residents were also invited to build 110 culinary booths.

Various developments to support tourism activities continue to be carried out. The 
home industry is cultivated by making drinks made of Curcuma, ginger, and saffron-colored rice in liquid and powder form. Other tourism alternative developments are Kelinci Park, Ndlundung Waterfall, and Sumber Gempong Water Tour. Currently, the average visit to Ganjaran park reaches 50,000 people monthly. Coffee plantation with Arabica and Robusta varieties is developed and marketed by opening a shop in Ganjaran Park. Local wisdom-based cultural development is developed by forming the Cultural Association. Cultural attractions are performed regularly at Ganjaran Park as one of the tourist attractions.

Tourism development aims to accelerate the Ketapan Rame Village community as a whole. The community can take the role of managing parking lot, BUMDES employees, toilet officers, facility managers, park investors, coffee plantation managers, coffee sellers, and opening souvenir centers, culinary, and other goods booths. Recently, Ketapan Rame Village consists of 1,879 households, and those involved in tourism activities reach 820 households.

After this program was launched in 2019, it provides some impacts as follows:

(1) An increase in the number of community participation to 820 households,

(2) An increase in community income,

(3) The creation of BUMDES income reaches IDR 335 million monthly from parking lot income, public toilets, booth rental, facility sharing, and swimming pool entrance tickets.

The selection of research objects is based on how this village is being developed into a tourist village. Thus, it is essential to know the community's perception of the impacts of tourism development and how public support is for the future development of this village.

\section{RESEARCH METHODS}

This study is a conclusive descriptive study and used primary data. The questionnaire was distributed to Ketapan Rame Village residents. The sampling technique used was non-probability sampling with a purposive sampling method, i.e., a sampling technique based on considerations or judgments related to characteristics that are suitable to be sampled (Zikmund, 2009: 396). SPSS was used to process primary data obtained from respondents.

\section{RESULTS AND DISCUSSIONS}

Respondents in this study were 154 . The data obtained through questionnaires were then processed by first testing the validity and reliability. Table 1 denotes the respondents' profile of this study.

Table 1. The Respondents' Profile Description

\begin{tabular}{ccc}
\hline Gender & Quantity & Percentage \\
\hline Male & 93 & 60.39 \\
Female & 61 & 39.61 \\
Position & Quantity & Percentage \\
Resident & 123 & 79.87 \\
Apparatus & 2 & 1.30 \\
Youth & 14 & 9.09 \\
organization & & \\
Immigrant & 12 & 7.79 \\
Others & 3 & 1.95 \\
Education level & Quantity & Percentage \\
Senior High & 120 & 77.92 \\
School & & \\
Diploma & 5 & 3.25 \\
Bachelor & 14 & 9.09 \\
Master & 1 & 0.65 \\
Doctoral & 1 & 0.65 \\
Others & 13 & 8.44 \\
Occupation & Quantity & Percentage \\
Student & 11 & 7.14 \\
Civil Servant & 2 & 1.30 \\
Entrepreneur & 26 & 16.88 \\
Private company & 55 & 35.72 \\
staff & & 15.58 \\
Housewife & 24 & 23.38 \\
Others & 36 & Percentage \\
Age & Quantity & 1.69 \\
17 - <20 & 18 &
\end{tabular}




\begin{tabular}{|c|c|c|}
\hline & & \\
\hline $20-<30$ & 34 & 22.08 \\
\hline $30-<40$ & 41 & 26.62 \\
\hline $40-<50$ & 33 & 21.43 \\
\hline 50 or more & 28 & 18.18 \\
\hline
\end{tabular}

Respondents were residents with high school as the final education level. Most of the respondents were private company staff. Respondents' ages ranged from 18 to more than 50 years. Many respondents do not have a regular income.

Table 2. Values of Factor Loading and Communalities of variables Environmental, Economic, Socio-Cultural, and Infrastructure

\begin{tabular}{|c|c|c|}
\hline Statement & $\begin{array}{l}\text { Factor } \\
\text { Loading }\end{array}$ & $\begin{array}{l}\text { Communa } \\
\text { lities }\end{array}$ \\
\hline \multicolumn{3}{|l|}{ Environmental } \\
\hline $\begin{array}{l}\text { Development of tourism } \\
\text { damage } \\
\text { natural environment and } \\
\text { landscape }\end{array}$ & 0.812 & 0.742 \\
\hline $\begin{array}{l}\text { Tourism causes } \\
\text { overcrowding problems for } \\
\text { residents }\end{array}$ & 0.852 & 0.782 \\
\hline $\begin{array}{l}\text { Tourism increases the air } \\
\text { pollution }\end{array}$ & 0.856 & 0.824 \\
\hline $\begin{array}{l}\text { Tourists use too much } \\
\text { water }\end{array}$ & 0.771 & 0.741 \\
\hline $\begin{array}{l}\text { Tourism produces more } \\
\text { waste in an area }\end{array}$ & 0.717 & 0.687 \\
\hline $\begin{array}{l}\text { Tourism development } \\
\text { negatively } \\
\text { affects the recreational } \\
\text { facilities and entertainment }\end{array}$ & 0.861 & 0.76 \\
\hline $\begin{array}{l}\text { The construction of tourist } \\
\text { facilities harms the } \\
\text { environment }\end{array}$ & 0.87 & 0.775 \\
\hline $\begin{array}{l}\text { Tourism increases traffic } \\
\text { problems }\end{array}$ & 0.438 & 0.659 \\
\hline Eigenvalue: 9.409 & & \\
\hline Variance (\%): $31.362 \%$ & & \\
\hline
\end{tabular}

\section{Economic}

Tourism plays an $-0.071 \quad 0.817$

important role in the economic development of the area

Tourism improves

$0.258 \quad 0.86$

residents' standard of

living

Tourism increases a village government's tax revenue

\begin{tabular}{|c|c|c|}
\hline $\begin{array}{l}\text { Tourism creates new jobs } \\
\text { for residents }\end{array}$ & 0.53 & 0.76 \\
\hline $\begin{array}{l}\text { Tourism diversifies the } \\
\text { rural economy }\end{array}$ & 0.534 & 0.76 \\
\hline $\begin{array}{l}\text { Tourism results in an } \\
\text { increase in the cost of } \\
\text { living }\end{array}$ & 0.846 & 0.802 \\
\hline $\begin{array}{l}\text { Revenue from tourism } \\
\text { taxes activity should be } \\
\text { invested in future tourism } \\
\text { development }\end{array}$ & 0.742 & 0.787 \\
\hline Eigenvalue: 1.406 & & \\
\hline Variance (\%): $4.6882 \%$ & & \\
\hline Socio-cultural & & \\
\hline $\begin{array}{l}\text { Tourism results in funding } \\
\text { for restoration of } \\
\text { traditional houses }\end{array}$ & 0.849 & 0.788 \\
\hline $\begin{array}{l}\text { Interaction with tourists is } \\
\text { a positive experience }\end{array}$ & 0.849 & 0.831 \\
\hline $\begin{array}{l}\text { Shopping and restaurants } \\
\text { option are better as a result } \\
\text { of tourism }\end{array}$ & 0.787 & 0.774 \\
\hline $\begin{array}{l}\text { Tourism development } \\
\text { enhance more recreational } \\
\text { opportunities for locals }\end{array}$ & 0.777 & 0.771 \\
\hline Eigenvalue: 5.347 & & \\
\hline Variance (\%): $17.824 \%$ & & \\
\hline Infrastructure & & \\
\hline $\begin{array}{l}\text { Tourism improves traffic } \\
\text { flow }\end{array}$ & 0.851 & 0.771 \\
\hline $\begin{array}{l}\text { Tourism improves living } \\
\text { utilities' infrastructure } \\
\text { (supply of water, waste } \\
\text { water, electric etc.) }\end{array}$ & 0.727 & 0.697 \\
\hline $\begin{array}{l}\text { Quality of public services } \\
\text { is better }\end{array}$ & 0.355 & 0.619 \\
\hline Eigenvalue: 1.055 & & \\
\hline Variance (\%): $3.515 \%$ & & \\
\hline
\end{tabular}

Table 3. Values of Factor Loading and Communalities of variables Sustainable Development and Development of Tourism Destination

\begin{tabular}{lcc}
\hline Statements & $\begin{array}{l}\text { Factor } \\
\text { Loading }\end{array}$ & Communalities \\
\hline $\begin{array}{l}\text { Sustainable } \\
\text { Development } \\
\text { It is important to } \\
\text { develop plans to } \\
\text { manage the growth of } \\
\text { tourism }\end{array}$ & 0.808 & 0.845 \\
$\begin{array}{l}\text { Long-term planning } \\
\text { will reduce the } \\
\text { negative environmental } \\
\text { impacts }\end{array}$ & 0.665 & 0.616 \\
\end{tabular}




\begin{tabular}{|c|c|c|}
\hline Cont. & & \\
\hline $\begin{array}{l}\text { I agree that local } \\
\text { authorities support } \\
\text { tourism development }\end{array}$ & 0.653 & 0.771 \\
\hline $\begin{array}{l}\text { New environment } \\
\text { protection measures } \\
\text { should be developed }\end{array}$ & 0.645 & 0.78 \\
\hline Eigenvalue: 1.856 & & \\
\hline Variance (\%): $6.217 \%$ & & \\
\hline $\begin{array}{l}\text { Development of } \\
\text { Tourism Destination }\end{array}$ & & \\
\hline $\begin{array}{l}\text { Tourism is a } \\
\text { sustainable activity in } \\
\text { my area/village }\end{array}$ & 0.799 & 0.735 \\
\hline $\begin{array}{l}\text { I support new tourism } \\
\text { facilities }\end{array}$ & 0.81 & 0.796 \\
\hline $\begin{array}{l}\text { My community should } \\
\text { become more of a } \\
\text { tourist destination }\end{array}$ & 0.629 & 0.632 \\
\hline $\begin{array}{l}\text { I support tourism and I } \\
\text { would like to see it } \\
\text { become an important } \\
\text { part of my community }\end{array}$ & 0.787 & 0.809 \\
\hline Eigenvalue: 2.265 & & \\
\hline Variance (\%) :7.55\% & & \\
\hline
\end{tabular}

The processing of each component shows the factor loading values above 0.5 , except for 4 statements below 0.5 . This shows that the statement cannot support the measurement of these variables so that it must be discarded in the measurement. Meanwhile, the values of communalities are above 0.6. While the total variance of $71.156 \%$ signifying the formation of 6 components of the Ketapan Rame residents' attitudes towards sustainable development and development of a tourist village.

Table 4. Mean and Standard Deviation Values of Environmental, Economic, Socio-Cultural, and Infrastructure Impacts

\begin{tabular}{lcc}
\hline Statement & Mean & $\begin{array}{l}\text { St. } \\
\text { Dev }\end{array}$ \\
\hline $\begin{array}{l}\text { Environmental } \\
\text { Development of tourism } \\
\text { damage } \\
\text { natural environment and }\end{array}$ & 3.66 & 0.71 \\
$\begin{array}{l}\text { landscape } \\
\text { Tourism causes overcrowding } \\
\text { problems for residents }\end{array}$ & 3.69 & 0.95
\end{tabular}

Cont.

\begin{tabular}{|c|c|c|}
\hline $\begin{array}{l}\text { Tourism increases the air } \\
\text { pollution }\end{array}$ & 3.53 & 0.97 \\
\hline Tourists use too much water & 3.14 & 1.02 \\
\hline $\begin{array}{l}\text { Tourism produces more waste in } \\
\text { an area }\end{array}$ & 2.98 & 1.03 \\
\hline $\begin{array}{l}\text { Tourism development } \\
\text { negatively } \\
\text { affects the recreational facilities } \\
\text { and } \\
\text { entertainment }\end{array}$ & 3.59 & 0.9 \\
\hline $\begin{array}{l}\text { The construction of tourist } \\
\text { facilities } \\
\text { damages the environment }\end{array}$ & 3.59 & 0.97 \\
\hline $\begin{array}{l}\text { Tourism increases traffic } \\
\text { problems }\end{array}$ & 2.68 & 1.08 \\
\hline Economic & 3.36 & 0.95 \\
\hline $\begin{array}{l}\text { Tourism plays an important role } \\
\text { in the } \\
\text { economic development of the } \\
\text { area }\end{array}$ & 1.66 & 0.72 \\
\hline $\begin{array}{l}\text { Tourism improves residents' } \\
\text { standard of living }\end{array}$ & 1.84 & 0.75 \\
\hline $\begin{array}{l}\text { Tourism increases a village } \\
\text { government's tax revenue }\end{array}$ & 2.27 & 0.99 \\
\hline $\begin{array}{l}\text { Tourism creates new jobs for } \\
\text { residents }\end{array}$ & 2.12 & 0.90 \\
\hline & 1.98 & 0.84 \\
\hline Socio-cultural & & \\
\hline $\begin{array}{l}\text { Tourism results in funding for } \\
\text { restoration of traditional houses }\end{array}$ & 2.92 & 0.96 \\
\hline $\begin{array}{l}\text { Interaction with tourists is a } \\
\text { positive } \\
\text { experience }\end{array}$ & 2.53 & 1.13 \\
\hline $\begin{array}{l}\text { Shopping and restaurants option } \\
\text { is } \\
\text { better as a result of tourism }\end{array}$ & 2.36 & 1.04 \\
\hline $\begin{array}{l}\text { Tourism development enhance } \\
\text { more } \\
\text { recreational opportunities for } \\
\text { locals }\end{array}$ & 2.44 & 0.97 \\
\hline & 2.56 & 1.02 \\
\hline Infrastructure & & \\
\hline Tourism improves traffic flow & 2.29 & 0.76 \\
\hline $\begin{array}{l}\text { Tourism improves living } \\
\text { utilities' infrastructure (supply } \\
\text { of water, waste water, electric } \\
\text { etc.) }\end{array}$ & 2.46 & 0.74 \\
\hline $\begin{array}{l}\text { Quality of public services is } \\
\text { better }\end{array}$ & 2.35 & 0.75 \\
\hline Total & 2.32 & 0.82 \\
\hline
\end{tabular}


The mean value of the environmental component has the highest perception, signifying that the community considers tourist village activities to lead to a negative impact on the environment of the Ketapan Rame village, such as more waste, congested traffic, and the environment can be damaged due to the construction of tourism facilities as well as the lack of maintenance of public facilities at the tourist attraction. However, the community also feels the positive impacts from the sociocultural aspect and infrastructure development because the community can interact with tourists and have the opportunity to introduce the village's processed products in culinary. The roads in the village and the water \& electricity supply for utilities are also getting better.

Table 5. Mean and Standard Deviation values of Sustainable Development and Development of Tourism Destination

\begin{tabular}{|c|c|c|}
\hline Statement & Mean & $\begin{array}{l}\text { St. } \\
\text { Dev }\end{array}$ \\
\hline \multicolumn{3}{|l|}{ Sustainable Development } \\
\hline $\begin{array}{l}\text { It is important to develop plans to } \\
\text { manage the growth of tourism }\end{array}$ & 1.91 & 0.72 \\
\hline $\begin{array}{l}\text { Long-term planning will reduce } \\
\text { the negative environmental } \\
\text { impacts }\end{array}$ & 2.18 & 0.80 \\
\hline $\begin{array}{l}\text { I agree that local authorities } \\
\text { support } \\
\text { tourism development }\end{array}$ & 1.74 & 0.70 \\
\hline $\begin{array}{l}\text { New environment protection } \\
\text { measures } \\
\text { should be developed }\end{array}$ & 1.90 & 0.71 \\
\hline & 1.93 & 0.73 \\
\hline \multicolumn{3}{|l|}{ Development of Tourism } \\
\hline $\begin{array}{l}\text { Tourism is a sustainable activity } \\
\text { in } \\
\text { my area/village }\end{array}$ & 1.84 & 0.66 \\
\hline I support new tourism facilities & 1.66 & 0.67 \\
\hline $\begin{array}{l}\text { My community should become } \\
\text { more of } \\
\text { a tourist destination }\end{array}$ & 1.84 & 0.76 \\
\hline \multirow{2}{*}{$\begin{array}{l}\text { I support tourism and I would } \\
\text { like to see it becomes an } \\
\text { important part of my community }\end{array}$} & 1.68 & 0.71 \\
\hline & 1.75 & 0.70 \\
\hline
\end{tabular}

The mean of respondents' perception towards sustainable development and development of tourism destinations in Ketapan Rame Village is still relatively low, signifying that the local community's attitude towards the development of a tourist village has not been positive. The local community has realized the tourist village development but not felt it is an integral part of their life.

Table 6 shows the results of the correlation value for each variable which shows that variables economic benefits, socio-cultural impacts, and infrastructure have a significant correlation to variable sustainable development. The same results can also be seen in the correlation between variable development of tourism destination. Meanwhile, the environmental impact and age variables do not show any correlation. Meanwhile, in Muresan et al. (2016), only variable age does not show any correlation with variables sustainable development and development of tourism destination.

Table 6. Correlation of each variable with the support for sustainable development and development of tourism destination

\begin{tabular}{|c|c|c|c|c|}
\hline \multirow{2}{*}{ Variable } & \multicolumn{2}{|c|}{$\begin{array}{l}\text { Sustainable } \\
\text { Development }\end{array}$} & \multicolumn{2}{|c|}{$\begin{array}{l}\text { Development of } \\
\text { Tourism } \\
\text { Destination } \\
\end{array}$} \\
\hline & $\begin{array}{l}\text { Correlati } \\
\text { on }(r)\end{array}$ & $\begin{array}{c}\mathrm{P} \\
\text { valu } \\
\mathrm{e}\end{array}$ & $\begin{array}{l}\text { Correlati } \\
\text { on }(r)\end{array}$ & $\begin{array}{c}\mathrm{P} \\
\text { valu } \\
\mathrm{e}\end{array}$ \\
\hline $\begin{array}{l}\text { Environmen } \\
\text { tal Impacts }\end{array}$ & 0.108 & $\begin{array}{c}0.18 \\
2\end{array}$ & -0.022 & $\begin{array}{c}0.78 \\
5\end{array}$ \\
\hline $\begin{array}{l}\text { Economic } \\
\text { Impacts }\end{array}$ & 0.658 & $* * *$ & 0.535 & $* * *$ \\
\hline $\begin{array}{l}\text { Socio- } \\
\text { Cultural } \\
\text { Impacts }\end{array}$ & 0.515 & $* * *$ & 0.365 & $* * *$ \\
\hline $\begin{array}{c}\text { Infrastructur } \\
\mathrm{e}\end{array}$ & 0.405 & $* * *$ & 0.432 & $* * *$ \\
\hline Age & 0.081 & 0.32 & 0.063 & $\begin{array}{c}0.43 \\
5\end{array}$ \\
\hline
\end{tabular}

Note: $* * * \operatorname{sig}<=0.01$

Source: Research data, processed 
Table 7. Results of t-test analysis of gender and support for future tourism development

\begin{tabular}{ccccc}
\hline \multirow{2}{*}{ Variable } & \multicolumn{2}{c}{ Mean } & \multicolumn{1}{c}{$\mathbf{T}$} & Sig. \\
Sustainable & 1.871 & 2.0246 & - & 0.135 \\
\cline { 2 - 5 } $\begin{array}{c}\text { Development } \\
\text { Development } \\
\text { of Tourism } \\
\text { Destination }\end{array}$ & 1.664 & 1.8893 & - & $0.018^{* *}$ \\
\hline
\end{tabular}

Note: $* * \operatorname{sig}<=0.05$

Source: Research data, processed

Table 7 depicts the results of the t-test analysis of gender and support for future tourism development. In variable sustainable development, there is no difference between male and female in supporting sustainable development, but there is a difference in gender factor in support for future tourism development. This is different from Muresan et al.'s (2016) results showing a difference in perceptions between males and females on variables sustainable development and development of tourism destination.

The t-test analysis of education level shows no difference between respondents who have the final education level of high school and diploma, bachelor's, and master's degrees in variables sustainable development and development of tourism destination. The results of this test are in line with Muresan et al. (2016) results.

Table 8. Results of t-test analysis of education level and support for future tourism development.

\begin{tabular}{ccccc}
\hline \multirow{2}{*}{ Variable } & $\begin{array}{c}\text { High } \\
\text { school }\end{array}$ & $\begin{array}{c}\text { >=Diplo } \\
\text { ma }\end{array}$ & T value & Sig. \\
\cline { 2 - 5 } $\begin{array}{c}\text { Sustainable } \\
\text { Development }\end{array}$ & 1.8214 & 1.9492 & -0.873 & 0.384 \\
$\begin{array}{c}\text { Development } \\
\text { of Tourism } \\
\text { Destination }\end{array}$ & 1.8214 & 1.7425 & 0.577 & 0.565 \\
\hline
\end{tabular}

\section{CONCLUSION}

Based on the results of this study and statistical tests carried out, it can be concluded that the most significant impact felt by the Ketapan Rame local community on tourism activities in their village is the environmental factor. The community feels a negative impact on the village's environment. However, the positive impacts are also felt from the socio-cultural aspect and infrastructure development in Ketapan Rame Village. The correlation test results show that variables economic, sociocultural, and infrastructure correlate to sustainable development and the development of tourist destinations in Ketapan Rame Village. Meanwhile the environmental and age variables do not show any correlation. The t-test analysis of gender shows that males and females differ in their support for developing tourism destinations but not sustainable development. Meanwhile, seen from the education level, there is no difference in their support for sustainable development and development of tourism destination.

The recommendation from this study results is that the government should have a village environmental protection program instructed to Ketapan Rame village tourists. The program should urge tourists to protect the environment by paying attention to waste, maintaining public facilities, and using the parking lot that has been provided. The recommendation for the next researcher is to choose other tourist village objects that can grow into a superior tourist village.

\section{REFERENCES}

Ap, John. 1992. Resident's Perceptions on Tourism Impacts. Annals of Tourism Research 19 (4):.665690.

Bakri, Norjanah Mohd, Mastura Jaafar, Diana Mohamad. 2014. Perceptions of Local Communities on the Economic Impacts of Tourism Development in Langkawi, Malaysia. Proceeding of $4^{\text {th }}$ International Conference on Tourism Research (4ICTR), Sabah, 9-11 December,2014, Sabah : EDP Science.

Bayram, Ali Turan, Ercan Karaçarb, Gül Erkol Bayram. 2018. Perceptions of Residents Towards The Impacts of Rural Tourism in Sinop Province. 
Journal of Tourism and Gastronomy Studies 6(2): $512-522$.

Brida, Juan Gabriel, Marta Disengage, Linda Osti. 2014. Residents' Perceptions of Tourism Impacts And Attitudes Towards Tourism Policies. Tourismos: An International Multidisciplinary Journal of Tourism 9 (1): 37-71.

Eshliki, Sajad Alipour \& Mahdi Kaboudi. 2012. Community Perception of Tourism Impacts and Their Participation in Tourism Planning: A Case Study of Ramsar, Iran Procedia - Social and Behavioral Sciences 36: 333 - 341

Kemenparekraf/Baparekraf RI. 2021. Desa Wisata Terus Tumbuh Sebagai Pariwisata Alternatif, https://www.kemenparekraf.go.id/Kebijakan/Desa -Wisata-Terus-Tumbuh-Sebagai-PariwisataAlternatif, 26 February 2021, assessed on 15 March 2021

Muresan, Iulia C., Camelia F. Oroian, Rezhen Harun, Felix H. Arion, Andra Porutiu, Gabriela O. Chiciudean, Alexandru Todea and Ramona Lile. 2016. Local Residents' Attitude toward Sustainable Rural Tourism Development. Sustainability 8 (100):1-14.

Zikmund, W. G., Babin, B. J., Carr, J. C. \& Griffin, M. 2009. Business Research Methods $\left(8^{\text {th }}\right.$ edition), USA: South-Western College Publishing. 